\title{
The Effects of Equal Caloric Amounts of Xylitol, Sucrose and Starch on Insulin Requirements and Blood Glucose Levels in Insulin-Dependent Diabetics
}

\author{
W. Hassinger, G. Sauer, U. Cordes, U. Krause, J. Beyer and K. H. Baessler \\ Abteilung für Endokrinologie und Stoffwechsel, II. Medizinische Klinik der Universität Mainz \\ Institut für physiologische Chemie der Universität Mainz, Federal Republic of Germany
}

Summary. Xylitol has been suggested as a potentially useful sweetener in the diabetic diet. In 14 insulindependent diabetics a standard diabetic diet regimen was compared with diets in which starch was isocalorically exchanged in the breakfast meal by either $30 \mathrm{~g}$ xylitol or $30 \mathrm{~g}$ sucrose. Insulin requirement and blood glucose were measured using a glucose-controlled insulin infusion system. The results following breakfast with xylitol were similar to those after starch breakfasts. Sucrose, in contrast, induced a greater post-prandial rise in blood glucose levels despite counter-regulation by the glucose-controlled insulin infusion system. Insulin requirement after sucrose significantly exceeded $(p<0.01)$ that after xylitol or starch during the first $60 \mathrm{~min}$ and $2 \mathrm{~h}$ respectively. No short-term side effects of xylitol were found.

Key words: Xylitol, sucrose, starch, insulin requirement, blood glucose, diabetes diet, isocaloric exchange, artificial pancreas, insulin dependent diabetes

The non-glucose carbohydrates, fructose and sorbitol, have been widely used for many years as diabetic sweeteners [24]. Xylitol has also been suggested in this role $[3,4,11,27]$. Its metabolism is largely independent of insulin $[12,18,20]$ and makes no major contribution to the glucose pool $[13,15,23]$. Compared with glucose or sucrose, xylitol leads to smaller increments in blood glucose level and in insulin requirement, in both healthy and diabetic individuals $[1,2,8,10,25,26]$. It has, however, been suspected that this advantage of xylitol administered alone may disappear when the sweetener is incorporated into a meal as part of a normal diabetic diet
[30]. The aim of the present study was to find out if there were differences in the blood glucose-induced insulin requirement when either xylitol or sucrose was substituted isocalorically for starch in one meal of a six-meal diabetic diet regimen.

\section{Materials and Methods}

\section{Patients}

Fourteen insulin-dependent diabetics were studied, with mean age $29 \pm 11$ SD years and mean percentage ideal body weight $102.4 \pm$ 7.5 SD. C-peptide concentrations were below $1 \mathrm{ng} / \mathrm{ml}$, both fasting and during the $6 \mathrm{~h}$ following test meals. None of the patients showed complications such as neuropathy, angiopathy or retinopathy. Apart from diabetes there were no endocrine or metabolic disturbances, and insulin was the only drug used. Patients with diseases of the liver, kidney or intestine or with previous gastrointestinal surgery were excluded. The aim of the study was explained to each patient and all gave their informed consent.

\section{Diet}

During the three days of investigation the patients received a diabetic diet providing the estimated calorie requirement at rest $(117 \mathrm{~kJ} / \mathrm{kg}$ body weight $=28 \mathrm{kcal} / \mathrm{kg}$ body weight $)$. Calorically the diet consisted of $40 \%$ carbohydrates, $40 \%$ fat and $20 \%$ protein. The diet was distributed over six meals: breakfast at $0800 \mathrm{~h}$, which was kept quantitatively constant in all patients; snack at $1000 \mathrm{~h}$; lunch at $1300 \mathrm{~h}$; snack at $1500 \mathrm{~h}$; dinner at $1800 \mathrm{~h}$; snack at $2100 \mathrm{~h}$. Intra-individually the meals were begun at exactly the same time. Calorie-free drinks were allowed ad libitum.

\section{Test Meals}

Breakfast was used to study the effects of an isocaloric exchange of starch by either xylitol or sucrose. It consisted of unsweetened tea or coffee ad libitum, $15 \mathrm{~g}$ evaporated milk (unsweetened), $20 \mathrm{~g}$ margarine (Becel), $50 \mathrm{~g}$ corned beef, $100 \mathrm{~g}$ cottage cheese and $36 \mathrm{~g}$ carbohydrate. The total calorie content was kept constant at $1880 \mathrm{~kJ}(=1450 \mathrm{kcal})$ in all individuals. The only variation in the 


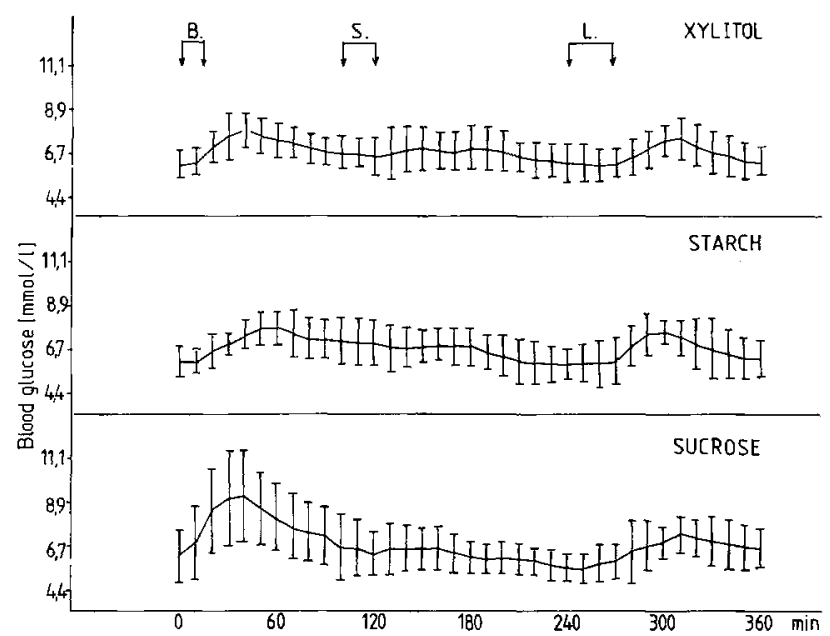

Fig. 1. Blood glucose levels ( $\mathrm{mmol} / \mathrm{l}$, means $\pm \mathrm{SD}$ ) at $10 \mathrm{~min}$ intervals following sucrose ( $n=14$ cases), xylitol ( $n=14$ cases) and starch ( $n=10$ cases) test meals. $\mathrm{B}=$ breakfast, $\mathrm{S}=$ snack, $\mathrm{L}=$ lunch. No significant differences (see text).

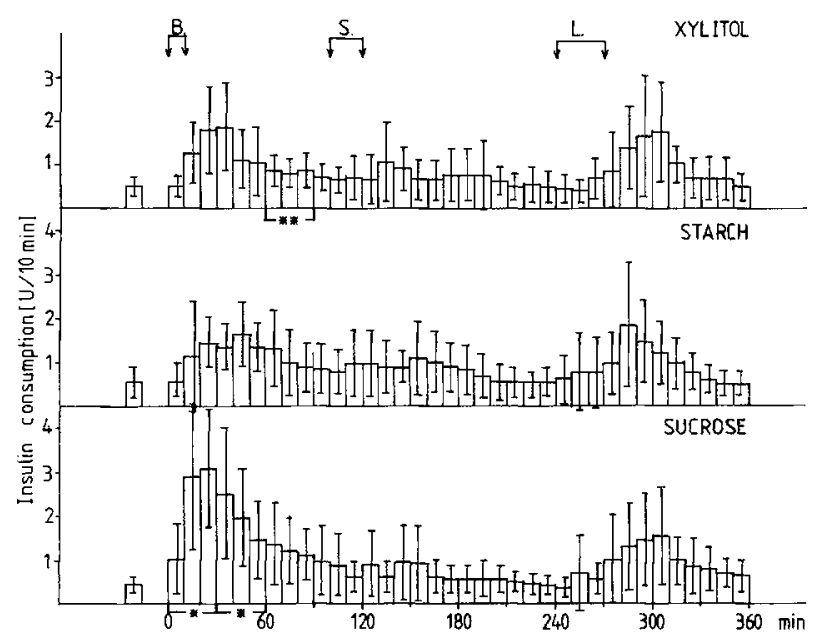

, Fig. 2. Insulin requirement (U/10 min; means $\pm \mathrm{SD}$ ) following sucrose $(n=14)$, xylitol $(n=14)$ and starch $(n=10)$ test meals. First column $=$ mean fasting insulin requirement in $U / 10 \mathrm{~min} \pm$ SD.

$* p<0.05$ compared with starch

$* * p<0.001$ compared with starch. $\mathrm{B}=$ breakfast, $\mathrm{S}=$ snack, $\mathrm{L}$ $=$ lunch

breakfast was with respect to the carbohydrate composition. In one test meal the total amount of $36 \mathrm{~g}$ carbohydrates consisted entirely of starch in the form of $75 \mathrm{~g}$ ryebread (hereafter referred to as "starch test meal"). In the other two test meals the carbohydrates consisted of $6 \mathrm{~g}$ starch in the form of $12.5 \mathrm{~g}$ ryebread, and $30 \mathrm{~g}$ sucrose ("sucrose test meal") or $30 \mathrm{~g}$ xylitol ("xylitol test meal"). Sucrose or xylitol were mixed with the cottage cheese. The other meals were identical on all three days and standardised for each patient. The sequence of the different test meals was randomized $(3 \times 3$ latin square). The breakfast test meals were commenced at time 0 and were eaten within 10-15 min. Patients were supervised to ensure total ingestion of all meals.

\section{Blood Glucose Levels and Insulin Requirement}

Blood glucose level and insulin requirement were measured and recorded at $1 \mathrm{~min}$ intervals by means of a Miles Biostator (glucosecontrolled insulin infusion system, GCIIS) as previously described [28]. The blood glucose was set to 4.4 to $6.7 \mathrm{mmol} / 1$ ( 80 to $120 \mathrm{mg} / \mathrm{dl}$ ). All patients were treated by the GCIIS overnight, starting between $1400 \mathrm{~h}$ and $1800 \mathrm{~h}$ on the day before the first test meal. The last SC insulin injection of short-acting or intermediateacting insulin was given at least $24 \mathrm{~h}$ before the first test meal. Once the protocol was begun, most of the patients were maintained on GCIIS treatment continuously for at least $74 \mathrm{~h}$. The first three patients, however, followed a test protocol for only $52 \mathrm{~h}$, comparing xylitol and sucrose test meals. In one of these the protocol was interrupted after $62 \mathrm{~h}$ because of technical problems. The other two patients were unwilling to continue beyond 62 and $64 \mathrm{~h}$ respectively; this was not related to meal palatability. A further patient ingested pure glucose on the starch test meal day and this day was excluded from evaluation. Unfortunately all these interruptions affected starch test days, despite random order of meals, but they did not appear to be related to palatability of the test meals.

\section{Xylitol and C-Peptide in Blood}

Venous blood was drawn before, 30 and 60 min after beginning the test meal and subsequently at each hour for $6 \mathrm{~h}$ for determination of xylitol and C-peptide. For xylitol determination the blood samples were immediately mixed with ice cold $1 \mathrm{~mol} / 1$ perchloric acid (1:3). Determinations were carried out enzymatically with 1-iditol-dehydrogenase [5]. Serum C-peptide was measured radioimmunologically as described by Kaneko et al. [17] using reagents provided by BYK-Mallinckrodt. The fasting normal range was from 1.1 to $3.6 \mathrm{ng} / \mathrm{ml} \mathrm{[19].}$

\section{Polyols in Urine}

Urine was collected for $12 \mathrm{~h}$ before and two consecutive $6 \mathrm{~h}$ periods after each test meal for polyol determination (1-iditoldehydrogenase) [5].

\section{Side-Effects, Taste}

The patients were questioned about sweetness and after-taste of the different test meals and about subsequent flatulence or diarrhoea.

\section{Evaluation of the Data}

Blood glucose levels and insulin requirements throughout the $6 \mathrm{~h}$ were analysed. Statistically the data were compared intra-individually by the paired, two-tailed Student's t test. Results are given as mean $\pm \mathrm{SD}$. Only the 10 patients completing the $74 \mathrm{~h}$ protocol are included in the analysis, but the random meal order was not disturbed as three of the four patients excluded were in the pilot study, which was not included in the full randomization process.

\section{Results}

\section{Blood Glucose Levels}

Figure 1 shows that blood glucose reached higher levels after sucrose (maximum $9.1 \pm 2.5 \mathrm{mmol} / \mathrm{l}$ at 
$40 \mathrm{~min}, \mathrm{NS})$ than after xylitol $(7.8 \pm 0.9 \mathrm{mmol} / \mathrm{l}$ at $40 \mathrm{~min}, \mathrm{NS})$ compared with starch test meal $(7.8 \pm$ $1.0 \mathrm{mmol} / 1$ at $50 \mathrm{~min}$ ). Following the peak caused by sucrose, blood glucose fell more quickly compared with xylitol or starch. Intra-individually there was no significant difference between the areas under the blood glucose curves following starch test meals (2026 \pm 2151$)$ and those following either sucrose $(3504 \pm 2311, \mathrm{NS})$ or xylitol $(1867 \pm 1981, \mathrm{NS})$.

\section{Insulin Requirement}

As shown in Figure 2 the sucrose test meals induced a rapid and substantial increase in insulin requirement during the first $2 \mathrm{~h}$ (cumulative insulin requirement at $60 \mathrm{~min} 12.5 \pm 5.4 \mathrm{U}$, at $120 \mathrm{~min} 18.8 \pm 6.0 \mathrm{U}$ ). In contrast following either xylitol or starch test meals insulin requirement rose more slowly (following xylitol cumulative insulin requirement at $60 \mathrm{~min} 7.6$ $\pm 2.1 \mathrm{U}$, at $120 \mathrm{~min} 12.4 \pm 2.9 \mathrm{U}$; and following starch at $60 \mathrm{~min} 7.3 \pm 2.2 \mathrm{U}$, at $120 \mathrm{~min} 13.2 \pm 3.4$ $U)$. Food-induced insulin consumption over the first hour was significantly higher after sucrose test meals than after starch meals $(0-30 \mathrm{~min} p<0.01$, $30-60 \mathrm{~min} p<0.05)$. In contrast food-induced insulin requirement was significantly lower between 60 and $90 \mathrm{~min}(p<0.001)$ after xylitol test meals than after starch. Fasting insulin requirements before the different test meals showed no significant differences. After lunch at $6 \mathrm{~h}$ after the test meals insulin requirement was still highest after sucrose test meal (36.9 \pm $9.4 \mathrm{U})$ and lowest after xylitol $(32.2 \pm 7.9 \mathrm{U})$. After starch test meals it was $35.8 \pm 7.9 \mathrm{U}$ ). Between hours 6 and 12 no difference in insulin requirements was found.

\section{Xylitol in Blood, Polyols in Urine}

The xylitol concentration in the blood after xylitol test meals was very low and at no time exceeded $0.6 \mathrm{mmol} / \mathrm{l}$. Three hours after the test meals xylitol was no longer detectable. Total urinary polyol excretion after xylitol test meals was $74 \pm 19 \mathrm{mmol} / \mathrm{h}$ amounting to a maximum of $0.8 \%$ of ingested xylitol. This showed no difference from polyol excretion after starch test meals $(80 \pm 22 \mathrm{mmol} / \mathrm{l})$.

\section{Side-Effects, Taste}

None of the patients experienced flatulence or diarrhoea after ingestion of xylitol-containing meals. Eleven patients reported no difference in taste between xylitol and sucrose test meals, but three patients felt that the xylitol test meal was too sweet.

\section{Discussion}

There is ample evidence that good control of the blood glucose level benefits diabetic patients, especially with regard to the late complications of diabetes $[6,7,16,21,22,26]$. Rapidly absorbed glucose-type carbohydrates, such as glucose or sucrose, should be avoided in the diabetic diet [8]. There is some controversy, however, as to whether replacement of sucrose by other nutritive sweeteners incorporated in regular meals facilitates metabolic control $[1,2,30]$. Our results clearly show that sucrose incorporated in a test meal induces a striking rise in blood glucose despite increased exogenous insulin administration by GCIIS. On the other hand, xylitol, which is more slowly absorbed in the gut [8] and gradually converted to glucose $[8,14]$ in the liver, behaves like starch as far as the effects on the blood glucose and insulin requirement are concerned. No short term side effects such as flatulence or diarrhoea could be observed after $30 \mathrm{~g}$ xylitol incorporated in one meal, but might be expected with amounts greater than $40 \mathrm{~g}$ [8]. Although intravenous infusion of xylitol may lead to overload, this does not occur with oral administration because intestinal absorption is limited. Long term investigations have failed to show any metabolic disturbances using oral xylitol in a dose of $50 \mathrm{~g}$ reasonably distributed over the day [29]. However, particularly in view of the cost of this substance further long term studies to determine patient acceptance are needed before considering xylitol for general use as a sweetener in the diabetic diet.

Acknowledgements. We thank Xyrofin AG, Baar, Switzerland for supporting this study.

\section{References}

1. Arvidsson-Lenner R (1976) Studies of glycemia and glucosuria in diabetics after breakfast meals of different composition. Am J Clin Nutr 29: 716-725

2. Arvidsson-Lenner R (1976) Specially designed sweeteners and food for diabetics- a real need? Am J Clin Nutr 29: 726-733

3. Bässler KH, Prellwitz W, Unbehaun V, Lang K (1962) Zur Frage der Eignung von Xylit als Zucker-Ersatz beim Diabetiker. Klin Wochenschr 40: 791-792

4. Bässler KH (1971) Die Rolle der Kohlenhydrate in der parenteralen Ernährung. Z Ernährungswiss (Suppl) 10: 57-58

5. Bässler KH, Wagner K, Schoenerstedt B (1978) Enzymatic determination of xylitol and sorbitol. J Clin Chem Clin Biochem 16: 547-550

6. Bloodworth JMB Jr (1973) Diabetes mellitus and vascular disease. Postgrad Med J 53: 84-89

7. Brunzell JD (1978) Use of fructose, xylitol or sorbitol as a sweetener in diabetes mellitus. Diabetes Care 1: 223-230

8. Dubach UC, Feiner E, Forgo I (1969) Orale Verträglichkeit 
von Xylit bei stoffwechselgesunden Probanden. Schweiz Med Wochenschr 99: 190-194

9. Foerster H, Boecker S, Walther A (1977) Verwendung von Xylit als Zuckeraustauschstoff bei diabetischen Kindern. Fortschr Med 95: 99-102

10. Foerster H, Steuer A, Albrecht R, Quadbeck R, Dudziak R (1978) Insulinkonzentration bei polytraumatisierten Patienten während Infusion von Glucose, Fructose und Sorbit. Infusionstherapie 5: $185-188$

11. Foerster H (1978): Verwendung von Zuckeraustauschstoffen in der diätischen Therapie. Med Mo Pharm 1: 42-53

12. Froesch ER, Zapf J, Keller U, Oelz O (1971) Comparative study of the metabolism of $\mathrm{U}_{-}{ }^{14} \mathrm{C}$-fructose, $\mathrm{U}^{-14} \mathrm{C}$-sorbitol and U-14-xylitol in normal and in the streptozotocin-diabetic rat. Eur J Clin Invest 2: 8-14

13. Froesch ER (1972) Übersicht über den Haushalt der Betriebs stoffe mit besonderer Berücksichtigung des Stoffwechsels von Glucose, Fructose, Sorbit und Xylit und deren therapeutische Verwendbarkeit. Int J Vitamin Nutr Res (Suppl) 12: 73-86

14. Gryborski D (1966) Diarrhoea from diabetic candies. N Engl J Med 275: 718-719

15. Haslbeck M (1974) Zur parenteralen Verabreichung von Zukkeraustauschstoffen mit besonderer Berücksichtigung des Diabetes mellitus. Infusionstherapie 1: 569-576

16. Joslin EP (1954) A renaissance of the control of diabetes Am Med Assoc 156: 1584-1585

17. Kaneko T, Oka H, Munemura M, Oda T, Yamashita K, Suzuki S, Yanaihara N, Hashimoto T, Yanaihara CH (1974) Radioimmunoassay of human proinsulin C-peptide using synthetic human connection peptide. Endokrinol Jpn 21: 141-143

18. Keller U, Froesch ER (1972) Vergleichende Untersuchung über den Stoffwechsel von Xylit, Sorbit und Fructose beim Menschen Schweiz Med Wochenschr 102: 1017-1022

19. Krause U, Cordes U, Beyer J (1977) C-Peptid-Sekretion und Stoffwechsel bei unterschiedlichen Funktionszuständen und Störungen der B-Zellen der Langerhansschen Inseln. Dtsch Med Wochenschr 102: 785-790

20. Lang K (1971) Xylit, Stoffwechsel und klinische Verwendung Klin Wochenschr 49: 233-245

21. Lundbaek K (1974) Diabetic angiopathy. Mod Concepts Cardiovasc Dis 43: 103-107
22. Matthews JD (1954) Vascular disease in diabetes mellitus. Lancet 2: $573-576$

23. McCormick DB, Touster O (1957) The conversion in vivo of xylitol to glycogen via the pentose phosphate pathway. J Biol Chem 229: 451-460

24. Mehnert H (1971) Über den relativen Wert von Zuckeraustauschstoffen und Süßstoffen in der Diabetesdiät. In: Zöllner N Calorienarme und calorienfreie Lebensmittel (ed), vol 20. Wissenschaftliche Veröffentlichung der Gesellschaft für Ernährung, Steinkopff-Verlag, Darmstadt pp 80-84

25. Mehnert H, Dietze G, Halsbeck M (1975) Zucker und Zukkeraustauschstoffe in der Diätetik von Störungen des Kohlenhydratstoffwechsels. Nutr Metab 118: 171-190

26. Mehnert H (1976) Zuckeraustauschstoffe in der Diabetesdiät. In: G. Ritzel, G. Brubacher (eds) Monosaccharide and polyalcohols in nutrition, therapy and diabetics. Int $\mathbf{J}$ Vit Nutr Res (Suppl) 15: 295-324

27. Mellinghoff $\mathrm{CH}$ (1961) Úber die Verwertbarkeit von Xylit als Ersatzzucker bei Diabetikern. Klin Wochenschr 39:447-448

28. Pfeiffer EF, Thum CH, Clemens AH (1974) The artificial beta cell - a continuous control of blood sugar by external regulation of insulin infusion (glucose controlled insulin infusion system). Horm Metab Res 487: 339-342

29. Scheinin A, Mäkinen KK (eds) (1975) Turku Sugar Studies I-XII. Acta Odontol Scand 33 (Suppl) 70

30. Talbot JM (1978) The use for special foods and sugar substitutes by individuals with diabetes mellitus. Prepared for Bureau of Foods, Food and Drug Administration, Department of Health, Education and Welfare, Washington, D.C. under contract no. FDA 223-75-2090. Life Sciences Research Office, Federation of American Societies for Experimental Biology, Bethesda, MD.

Received: 25 June 1980

and in revised form: 24 February 1981

W. Hassinger, M. D.

Abteilung für Endokrinologie und Stoffwechsel

II. Medizinische Klinik und Poliklinik der Universität Mainz

Langenbeckstr. 1

D-6500 Mainz,

Federal Republic of Germany 